\title{
Analysis of production resources improvement strategies in make-to-stock environments managed by the simplified drum-buffer-rope system
}

\author{
Análise de estratégias de melhoria de recursos produtivos em \\ ambientes make-to-stock gerenciados pelo sistema tambor-pulmão- \\ corda simplificado
}

\author{
Humberto Govoni ${ }^{1}$ (), Fernando Bernardi de Souza ${ }^{1}$ (ㄱ), Robson Flávio Castro ${ }^{2}$ (1), \\ José de Souza Rodrigues ${ }^{1}$ (1), Silvio Roberto Ignacio Pires ${ }^{3}$ (1) \\ ${ }^{1}$ Universidade Estadual Paulista, Departamento de Engenharia de Produção, Bauru, SP, Brasil. E-mail: \\ humberto.govoni@unesp.br; fernando.bernardi@unesp.br; jose.rodrigues@unesp.br \\ ${ }^{2}$ Universidade Federal de São Carlos, Departamento de Engenharia de Produção, São Carlos, SP, Brasil. E-mail: \\ robson.castro@ufscar.br \\ ${ }^{3}$ Fundação Getúlio Vargas, Departamento de Administração, Rio de Janeiro, RJ, Brasil. E-mail: sripires@fgvmail.br
}

How to cite: Govoni, H., Souza, F. B., Castro, R. F., Rodrigues, J. S., \& Pires, S. R. I. (2021). Analysis of production resources improvement strategies in make-to-stock environments managed by the simplified drum-buffer-rope system. Gestão \& Produção, 28(4), e55. https://doi.org/10.1590/1806-9649$2021 \mathrm{v} 28 \mathrm{e} 55$

\begin{abstract}
Theory of Constraints (TOC) states that every system has a single constraint that limits its performance, on which improvement efforts should be concentrated. This paper compared, through computer simulation, several methods of identifying the capacity-constrained resource in the perspective of a process of continuous improvement. Six make-to-stock (MTS) production line configurations managed by the Simplified Drum-Buffer-Rope (S-DBR) system were simulated, in which six improvement methods were applied, three of them based on the TOC literature, and their performance measured and compared in terms of cycle time and order fill rate. The results showed that, in balanced systems, improvements spread over all resources allowed better results, because, in this case, it is necessary to improve everything to benefit the overall performance. In unbalanced environments, on the other hand, the three methods recommended by TOC, which recommend efforts concentrated on the weakest point of the system, achieved superior performance, with emphasis on the strategy based on the level of utilization. In addition to advancing the frontiers of knowledge in continuous improvement and TOC, the research results show that managers should focus their attention on the resource with the highest degree of utilization to get better and faster performance gains.
\end{abstract}

Keywords: Continuous improvement; Theory of Constraints; Simplified Drum Buffer Rope; Make-to-availability; Simulation.

Resumo: A Teoria das Restrições (Theory of Constraints - TOC) afirma que todo sistema possui uma única restrição que limita seu desempenho, na qual os esforços de melhoria deveriam ser concentrados. Este artigo comparou, mediante simulação computacional, diversos métodos de identificação do recurso com restrição de capacidade na perspectiva de um processo de melhoria contínua. Foram simuladas seis configurações de linha de produção make-to-stock (MTS)

Received 17/nov/2020 - Accepted 28/july/2021

Financial support: None. 
gerenciadas pelo sistema Tambor Pulmão Corda Simplificado (TPC-S), nas quais foram aplicados seis métodos de melhoria, três deles fundamentados na literatura da TOC, e seus desempenhos medidos e comparados em termos de tempo de ciclo e taxa de preenchimento de pedidos. Os resultados demonstraram que, em sistemas balanceados, melhorias espalhadas por todos os recursos permitiram melhores resultados, pois, neste caso, é necessário melhorar tudo para beneficiar o desempenho global. Em ambientes desbalanceados, por outro lado, os três métodos recomendados pela TOC, os quais recomendam esforços concentrados no ponto mais frágil do sistema, alcançaram desempenho superior, com destaque para a estratégia baseada no nível de utilização. Isto permite que, na prática, gestores possam concentrar suas atenções no recurso com maior grau de utilização, tornando mais rápida a implementação das melhorias e a percepção dos benefícios alcançados.

Palavras-chave: Melhoria contínua; Teoria das Restrições; Tambor Pulmão Corda Simplificado; Produzir para disponibilidade; simulação.

\section{Introduction}

In an increasingly competitive scenario, it is imperative that industrial organizations continually improve their manufacturing processes. In this way, substantial efforts have been devoted to the research and practice of strategies, methods and technologies aimed at the improvement of production systems (Li et al., 2016).

In more than 50 years in which continuous improvement has been discussed by academics, several approaches have emerged from its implementation in organizations, such as Lean Manufacturing, focused on waste reduction (Womack et al., 1990); Six Sigma, which seeks to eliminate process variations (Pyzdek, 2003); and the Theory of Constraints (TOC), whose objective is to focus attention on the resources that restrict the flow of products or money generation (Goldratt \& Cox, 2014).

The basic characteristic of TOC is to schedule production according to the pace of the constraint (drum), protecting it from process variability with a certain amount of inventory (buffer), and ensuring that the rest of the plant works according to the constraint needs (rope). If the constraint is internal to the production system, it is said that there is a bottleneck, since the lack of capacity in one or more resources is the limiting factor for the company to generate more money. In other scenarios, this limitation may be in market demand, which suggests that there is excess capacity in the system resources.

In the first case, in which the Drum-Buffer-Rope (DBR) method is used to schedule and control the production, the basic idea is that the bottleneck resource works at its maximum capacity so that the system can handle as many orders as possible. In the second, usually handled using the Simplified Drum-Buffer-Rope (S-DBR) method, even the constrained resource has some surplus capacity (Schragenheim \& Dettmer, 2001). The implementation of the latter differs in make-to-order (S-DBR/MTO) and make-tostock (S-DBR/MTS, or S-DBR/MTA, for make-to-availability) environments.

In order to put a continuous improvement process into practice, from a TOC perspective, Goldratt \& Cox (2014) present an approach consisting of five steps, which are based on the identification of the constraint in the system and the correct action on it to obtain a disruption solution. Kasemset \& Kachitvichyanukul (2010) point out that identifying the constraint is the key to implementing TOC and trigger an effective improvement process, since it limits the performance of the system. Once the constraint has been found, the next steps for improving the system can definitely work. 
There are two simple ways to identify a physical constraint (Goldratt \& Cox, 2014; Wang et al., 2011). The first one is targeted at the amount of work in progress, that is, the queue of jobs waiting to be processed in each of the resources. The second is targeted at the capacity of the equipment, based on the daily work load in these resources. For example, if a resource produces at almost $100 \%$ of the time, it probably limits the system's throughput (Reid, 2007).

The Buffer Management (BM) offers a third approach, since it monitors the dynamics of the red orders in the system (orders that have consumed more than two thirds of the buffer and are not yet available for the constraint). If the buffers are at the correct size, these orders must occur in small amounts, allowing them to be rushed and to create a systematized mechanism for analyzing their causes (Schragenheim \& Dettmer, 2001). A systematic attack on the causes of these obstructions should ultimately result in the continuous improvement of the system.

To assess the performance of these improvement strategies, a contemporary production planning and control approach was chosen: the simplified drum-buffer-rope. Besides that, the research develops in an actual MTS production environment, modeled computationally with the software Promodel. It is worth mentioning that the vast majority of research in DBR, and especially in S-DBR method, was developed in make-to-order production systems (Kuo et al., 2009; Lee et al., 2010; Chang \& Huang, 2014; Hinckeldeyn et al., 2014).

Several studies have sought to study the impact of different improvement strategies recommended by TOC on the overall performance of the plant (Goldratt \& Fox, 1986; Goldratt, 1990; Schragenheim \& Ronen, 1991; Umble \& Umble, 2006; Umble et al., 2006; Lee et al., 2010; Souza \& Baptista, 2010; Stratton \& Knight, 2010; Goldratt \& Cox, 2014). Other publications have similar purposes to this research because they involve the quantitative evaluation of several improvement methods, but use a different analysis approach: System Dynamics (Godinho \& Uzsoy, 2013, 2014).

In searches performed on Scopus and Web of Science databases, Ikeziri et al. (2018) identified 155 articles published in journals that addressed the TOC from the perspective of continuous improvement processes. However, none of them proposes to quantitatively analyze different improvement strategies from a computational simulation approach, adopting the BM method as a strategy to improve productive resources. Ikeziri et al. (2018) highlighted this point as a gap or opportunity for future research. Even at the time of conducting this research, no scientific studies have been found that have modeled and quantified the possible benefits of this strategy. This is a distinctive and pioneering feature of this research. Therefore, due to the lack of studies on the S-DBR/MTA and BM methods and because of the simulation approach chosen, this is unprecedented research in TOC improvement strategies.

In order to evaluate the effectiveness of the TOC improvement strategies, this article aims to quantitatively compare them to other two, not in line with the TOC assumptions: random improvements resulting from an unsystematic process of identifying a target for improvement and scattered improvements across all resources, reflecting the Kaizen strategy of small and continuous improvements throughout the plant. A sixth scenario represents the absence of improvements and will serve as a reference to quantify the effectiveness of performance gains of the others. In summary, the following approaches were evaluated:

- No improvements;

- Random improvements;

- Improvements in all resources; 
- Improvement in resources that have the largest queues;

- Improvement in the resources with the highest levels of utilization;

- Improvement in the resources that create red orders (based on buffer management method).

TOC recommends that the production system to be unbalanced, that is, nonconstrained resources must have excess capacity in relation to the capacityconstrained resource (Chakravorty \& Atwater, 2006; Souza \& Pires, 1999; Souza et al., 2002; Goldratt \& Cox, 2014; Pacheco et al., 2014). In fact, Goldratt (2009) says that the primary purpose of manufacturing is to maximize flow, not resource efficiency. The corollary of this statement is that operations should focus on balancing flow, not capacity.

Since the differences in capacities between resources can directly influence the effectiveness of improvement strategies, different degrees of imbalance should be assessed. Other strategies, on the other hand, such as dispersed improvements among all resources, start from the assumption that balanced lines are ideal configurations. As such, the effect of the presence of balanced lines, as well as the level of resource utilization, should also affect the results of different improvement strategies.

As such, the five strategies of improvements mentioned were submitted to six different configurations of production systems:

- Balanced with $75 \%$ load on all resources;

- Balanced with $85 \%$ load on all resources;

- Balanced with $95 \%$ load on all resources;

- Unbalanced with $75 \%$ load on capacity-constrained resource;

- Unbalanced with $85 \%$ load on capacity-constrained resource;

- Unbalanced with $95 \%$ load on capacity-constrained resource.

This study intends to contribute to a very restricted niche of work that deals with some overlapping themes: analysis of different TOC strategies of improvements applied in MTS environments with various capacity configurations of its resources and managed using the S-DBR method. Thus, in addition to the originality of the proposal, the research is justified by quantifying the potential benefits of each improvement strategy in an MTS environment managed by the S-DBR / MTA and BM methods. This subject can also be of great interest to professionals looking at process improvement, since different choices can result in different impacts on organizational performance, allowing savings on resources and supporting a competitive advantage.

The method chosen to conduct this research was the computer simulation, which, besides permitting to model real-world processes, systems or events (Law \& Kelton, 2000), allows the theory development when simple theory exists (Davis et al., 2007). Simple theories, according to these authors, are the ones that are neither welldeveloped, which lack research opportunities, nor "clean-slate", which still lack the minimum understanding to allow the construction of a reliable model.

The article then presents a brief summary of the literature dedicated to conceptualizing traditional continuous improvement, addressing, in the sequence, the TOC and its perspective of continuous improvement. The other sections of the article present the method used in the research, the results obtained with the simulation and, finally, the conclusions of the study. 


\section{Literature review}

This section presents a literature review of the main issues addressed in this research, which includes the continuous improvement and its contributions to TOC, the S-DBR/MTA system and strategies to improve resources in a production line.

\subsection{Traditional aspects of continuous improvement}

The origins of modern improvement programs date back to the nineteenth century, when managers encouraged employee improvements and rewarded them for bringing positive ideas to the organization (Schroeder \& Robinson, 2017). Since then, forms of improvement have evolved greatly and, currently, advances in information, technology, intensification of competition and shifting markets have contributed to innovations in improvement (Li et al., 2016).

Schroeder \& Robinson (2017) identify some assumptions for the success of improvement programs:

- Improvements need time to prove to be effective.

- Operational practices that restrict the flow of ideas must be abolished.

- Employees must be continuously trained and developed, particularly in improvement method techniques.

- An efficient mechanism is needed to deal with improvement ideas that arise.

The subject of improvement can be divided into two approaches: one is characterized by being gradual and continuous, while the other is radical and sporadic. The first one, also known as Kaizen, seeks to put the idea of always seeking improvement into the minds of people, whether in their personal or professional life or in the environment in which the individual is included (Imai, 1986). In Japanese, Kaizen means "continuous improvement," an expression that suggests improvements that involve everyone - from managers to workers - and require relatively little investment.

The second approach, known as the Japanese expression Kaikaku, is a large-scale improvement that involves the redesign of production-related processes with the aim of achieving dramatic improvements (Hammer \& Champy, 2002). Unlike Kaizen, where the initiative comes from the operators themselves, Kaikaku is usually a top-down approach, which involves product, process or even concept change (Kurdve et al., 2016).

Figure 1 shows the behavior of these two approaches in a performance chart over time.

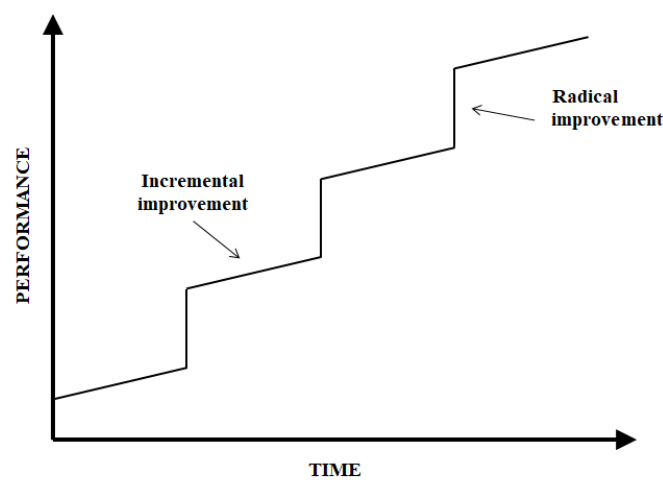

Figure 1. Radical improvement vs. incremental improvement. Source: Imai (1986). 
Slack et al. (2009) argue that radical improvement gives great value to creative solutions and encourages free thinking and individual initiative, while continuous improvement is built from accumulated experience within the operation and favors adaptability, group work and attention to detail.

\subsection{Continuous improvement on the shop floor and the TOC perspective}

The method of production planning and control dictated by the TOC presumes that every system must be managed from its constraint, that is, the resource that most restricts the flow of production orders. Once the constraint has been identified, the rest of the system must work hard enough to support it, generating as little work in progress (WIP) as possible.

Because all other resources have more capacity than the constraint, Goldratt \& Cox (2014) argue that output of the production line is restricted by what the constraint can produce. In other words, if the constraint manages to produce one more part per hour, the whole system produces one more part per hour. In contrast, if a non-constraint produces one more part per hour, this is not reflected in the benefit to the system. Thus, according to the TOC, for the system to achieve higher overall levels of production, efforts should be focused on system constraints.

The general process of improving the Theory of Constraints is guided by the answers to four questions. They can be applied at any organizational level and in any industry, ranging from political constraints to the shop floor (Barnard, 2010):

(1) Why change? - To see the difference between a current situation and future situation and to convince everyone that change is necessary;

(2) What to change? - Identify the point that, if changed, will positively affect the system as a whole;

(3) To what to change? - Find simple and practical solutions to change;

(4) How to cause the change? - Managing change in a way that the people involved in the change process understand the underlying rationale and the expected individual and systemic benefits from it.

The result of the answers to these questions is a continuous improvement process with characteristics of radical improvement when the constraints are political and efforts are focused on the organization's procedural or paradigm changes.

The TOC also proposes a five-step focused methodology to structure its process of continuous improvement, specifically involving physical resource management (Goldratt \& Cox, 2014), which is similar to the PDCA cycle with respect to continuity of the cycle (Schragenheim \& Dettmer, 2001):

(1) Identify the constraint(s) in the system

(2) Decide how to exploit the constraint(s) in the system

(3) Subordinate everything to the previous decision

(4) Elevate the constraint(s) of the system

(5) If, in a previous step, a constraint has been disrupted, go back to the first step, but do not let the inertia cause a system constraint.

As such, the result of an improvement process that follows the five steps and/or the four questions is a type of improvement that focuses on a constraint and consequently in increasing the throughput of the system (and not cost savings). As a consequence, 
it can lead to disruptive solutions, characterized by jumps in performance in accordance with a kind of radical improvement process.

The result of many improvements over time may lead to increased performance in the system, but these changes may also bring certain instability. Goldratt (2010) and Barnard (2010) point out two conditions that are necessary for companies to always be prosperous: the exponential growth of financial results coupled with the growth of the organization's stability.

For this to occur, major customers' needs must be attended to in a manner that no other competitor can achieve, which is commonly known as Decisive Competitive Edge (DCE). Thus, the objective is simultaneously to capitalize on the DCE, achieving an ever-increasing growth rate, in addition to sustaining it, stabilizing the system even in a situation of increasing demand.

It can be seen that, in order to constantly have a DCE, a systematic process of creation and implementation of disruptive solutions is needed, which reinforces the search for radical improvements in the TOC. However, in the interval between such radical improvements, incremental improvements are needed (Schragenheim et al., 2009), which can be accomplished by applying tools from other management systems such as Lean or Six Sigma.

In this case, these incremental improvements always aim at: a) an increase in the capacity of the system constraint; b) better exploitation of the system constraint; or c) better subordination to the system constraint (Goldratt \& Cox, 2014). The Buffer Management (BM) technique mainly seeks to support item "c" (Schragenheim \& Ronen, 1991; Schragenheim \& Dettmer, 2001). If the constraint is on the market, the $\mathrm{BM}$ is not a tool that acts directly on it, but aims to improve the system so that it can submit to the interests of consumers, sustaining the DCE achieved. In a less structured manner, other ways of focusing on improvements in productive resources could be based on those with higher levels of utilization or with the largest quantities of work in progress waiting processing.

Some studies sought to address the impact that improvements in productive resources have on the system's performance. Godinho \& Uzsoy (2011) developed a system dynamics model based on the Factory Physics (Hopp \& Spearman, 2000) to assess the effect of different continuous improvement programs on the relationship between lot sizes and cycle times. Also based on system dynamics modeling and on Factory Physics concepts, Godinho \& Uzsoy (2014) evaluated the cumulative effect of continuous improvement in arrival variability, process variability, defect rate, time to failure, repair time and set-up time in a flow-shop environment. They observed that improvements at non-bottleneck stations allow significant benefits by reducing the variability of flow to the bottleneck. Through a simulation in a flow shop environment producing a single type of product, Godinho \& Utiyama (2015) compared two strategies for the allocation of improvement: focused on the capacity constraint resource and distributed along the production line. Their results showed that when the utilization of the constrained resource is high and the difference in the processing time between the constrained resource and the non-constrained resource is significant, focusing on the capacity constraint resource is the best choice. Godinho \& Barco (2015), in turn, address different lean improvement strategies, adding, however, the cost variable to their models. Through computer simulation, Godinho \& Utiyama (2016) studied the effects on lead time when repair lead time is reduced from one of three strategies: repair time mean, repair time variability or eliminating the worst cases repair times. 
Wu et al. (2020) state that the definition of bottleneck presented by TOC, "any resource whose capacity is equal to or less than the demand placed upon it" (Goldratt \& Cox, 2014), is limited, does not properly consider the effects of variability and neither it is strict from the point of view of queuing systems. From a mathematical modeling based on queuing systems, later demonstrated in case studies, the authors concluded that improvements in frontend stations allow greater impact on system performance when compared to improvements focused on the bottleneck station.

\subsection{The S-DBR/MTA system and strategies to improve factory resources}

The production systems managed by the TOC operate under a pull production technique called Drum-Buffer-Rope (DBR). The fundamental idea of this technique is that the amount the whole system can produce is equal to the amount the resource with the least available capacity can process. Such a resource is called capacityconstrained resource (CCR), defined here as "any resource that, if its capacity is not carefully managed, is likely to compromise the throughput of the organization" (Cox et al., 2012, p. 20). As such, the production environment is managed based on its capacity constraint. The technique asserts that, when the CCR is also a bottleneck, it must work as much as possible, while the other resources must only work on what is needed to support it.

The presence of an active CCR, or bottleneck, such as in the classical DBR method, raises a number of questions that need to be answered, such as not allowing the market constraint to be exploited to its full potential, the difficulty in rescheduling the bottleneck to introduce a more urgent order or the blockage in the production flow itself (Schragenheim, 2010).

In order to deal with these issues, the Simplified Drum-Buffer-Rope (S-DBR) was developed, where the main premise is that market demand is the main constraint, even in the presence of an internal capacity constraint (Souza \& Baptista, 2010).

Perhaps because this is a contemporary concept, little research has been carried out on the S-DBR system. In research carried out on the Scopus and Web of Science databases, only nine papers published in journals involving the S-DBR method were identified. Of these, eight addressed applications in MTO environments (Lee et al., 2010; Souza \& Baptista, 2010; Kim et al., 2010; Chang \& Huang, 2011a, b, 2014; Benavides \& Van Landegheim, 2015; Chakravorty \& Hales, 2016), while only one approached the MTA method (Souza \& Pires, 2014).

Lee et al. (2010) address some difficulties that some production environments may impose when implementing the S-DBR in MTO environments. Souza \& Baptista (2010) propose an advance for the S-DBR system, with regard to promises of urgent deliveries in the production to order. After employing the evaporating cloud method to show the traditional dilemma of increasing work-in-process (WIP) to fully utilize resources versus decreasing WIP inventory to reduce cycle time, Kim et al. (2010) simulate an unbalanced re-entrant line with fixed capacity to explore the effectiveness of using protective inventory by changing the level of WIP on two dependent variables: cycle time and throughput. From a proposal for a production order sequencing method based on layer production buffer to monitor the status of the buffer (Chang \& Huang (2011a, b), Chang \& Huang (2014) proposed an enhanced simplified drum-buffer-rope (SDBR) model to be applied in a reentrant flow shop (RFS). More recently, applications of the S-DBR system have been studied, as in small and medium-sized companies, due to the simplified planning characteristics of such a system (Benavides \& Van Landegheim, 
2015), or in assessing the performance of work relationships (Chakravorty \& Hales, 2016).

Until the S-DBR, all TOC methods of production planning and control had focused on make-to-order (MTO) environments. More recently, because of the need to ensure high availability of certain products so that they can be withdrawn at the time of purchase, the applicability of the method has been expanded to MTS environments. The TOC proposal for the MTS environment was introduced and extensively addressed by Schragenheim et al. (2009), who called it make-to-availability (MTA). MTA is a general statement of a producer that proposes to provide immediate supply whenever necessary (Souza \& Pires, 2014).

Figure 2 shows an S-DBR/MTA production system, where the drum is the final product consumption rate adjusted by the availability of the capacity constrained resource, the rope is the regulation of raw materials according to the rhythm of the drum, and the replenishment time is the time taken to process the raw materials into finished goods.

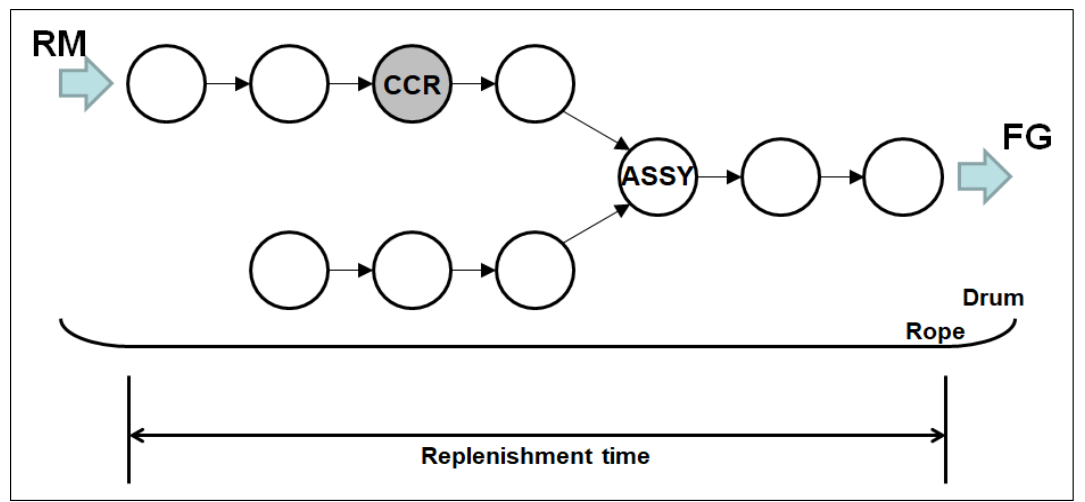

Figure 2. The S-DBR/MTA system. Source: Adapted from Schragenheim et al. (2009).

According to Schragenheim et al. (2009), the MTA production method is based on five basic principles, listed below:

(1) Inventory and replenishment times are strongly correlated

Minor replenishment times require less inventory to ensure availability and avoid loss of sales, in addition to allowing a more accurate sales forecast.

Unfinished production orders are also part of the protection. The idea behind this is that while work in progress is not readily available to clients, much of it is close to being available.

(3) Tomorrow will be similar to today

Whenever finished goods are consumed, a new production order must be opened. This allows the replenishment time to be kept as short as possible and to have a relatively constant stock level. In this sense, the release of material for the production system (Rope) is due to the consumption of FGI (finished goods inventory) by the market (Drum).

(4) The status of finished goods inventory dictates production priorities

Priority for production orders must be given taking the difference between the current finished goods inventory and the system target level set. Figure 3 shows a 
representation for the target level, as given by Schragenheim (2010). It is a planned inventory sufficient to attend the maximum demand of a particular SKU (stock-keeping unit) during the cycle time of the system, which considers both FGI and WIP. The target level is the buffer in an S-DBR/MTA system. Therefore, each SKU has one and only one target level (buffer). The buffer penetration is the quantity consumed - for each SKU - of FGI which was not yet replaced (Schragenheim, 2010).

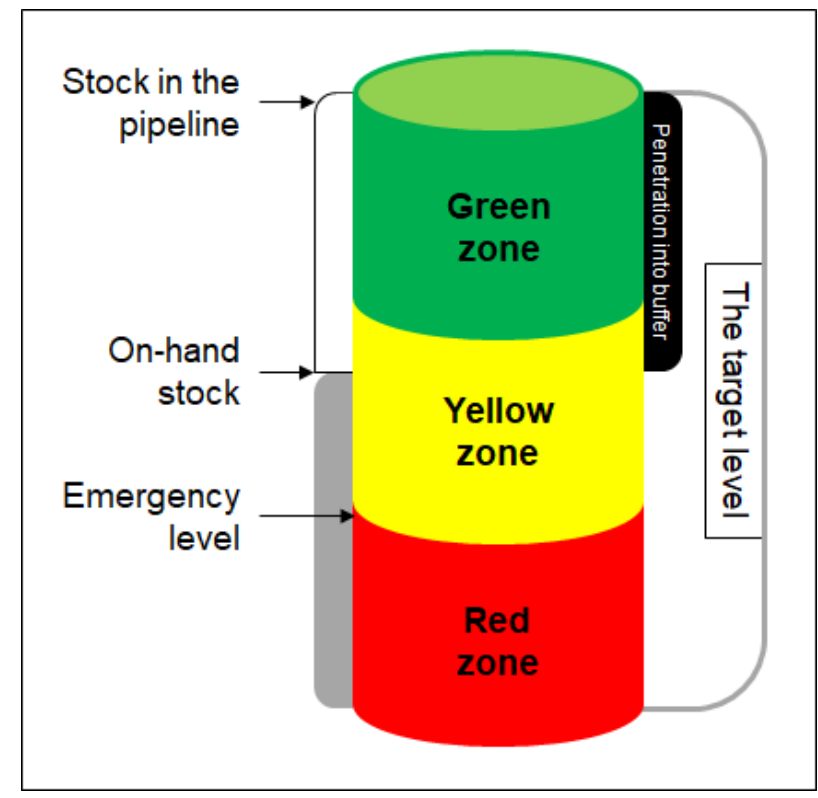

Figure 3. Target level. Source: Schragenheim (2010).

The application of the concepts of Rope and Drum, in addition to the priorities of the orders established by their status, allows the synchronization of all production in a pulled way, since stocks are limited (Hopp \& Spearman, 2004). The priority levels of the production orders are:

- Green. When the FGI level is two thirds or more of the target level, it means that there is sufficient inventory to assure the availability of an item in the moment. This way, the orders have the lowest priority compared to the others.

- Yellow. When the FGI level is between two thirds and one third of the target level, it means that there is no urgency in producing an item, but the inventory is not that high. These orders receive an intermediate priority.

- Red. When the FGI level is less than one third of the target level, it means that there is a great risk not to have enough products to meet the demand. Thus, these orders acquire the maximum priority in the system.

(5) Stagnation is undesirable

If an item has a green or red status for a long time, it means that the target level needs correction. For this, if an item remains as a green status for a long time, there is more inventory than needed and hence the target level can be reduced. On the other hand, if it often enters the red zone of the buffer, there is a risk of missing products to meet the demand and the guidance is to increase the target level (Schragenheim et al., 2009). 
The BM suggests that, when an order has turned red, where that order went and the reasons why that made it late must be investigated. Periodically, the main reasons for obstruction to flow are analyzed and improved. With the improvements, buffers can become smaller, which decreases the amount of WIP in the system and production lead time (Gardiner et al., 1993). As such, as stated by Schragenheim (2010), the BM provides a strategy to improve production resources based on identifying the main obstacles to the production flow.

In addition to BM, the TOC recommends two other approaches to identify constraints. The first one measures the use of different system resources (Law \& Kelton, 2000). In this case, the machine with the highest level of use is considered the constraint. However, machine uses can be very similar and do not clearly indicate the constricting resource (Roser et al., 2002). This method, according to the authors, is not useful to identify momentary constraints, only the mean over large periods of time.

The second is addressed by the size of the queue or by the waiting time in the resources. Because it is visual and not dependent on accurate data, this strategy is recommended by Goldratt in the book "The Goal" (Goldratt \& Cox, 2014). Roser et al. (2002) claim that it is an easy-to-use method, even allowing momentary constraints to be found. However, they point out some negatives such as:

- In systems where the release of work exceeds the capacity of the line, the number of jobs in the production queues reaches the maximum buffer size and therefore cannot be compared;

- The possibility of giving incorrect results if the size of production lots varies between entities;

- The queues are dependent factors, which makes it difficult to estimate the average queue between the resources.

White et al. (2012) suggest two methods besides those mentioned above: (i) resources with the highest active state without interruptions, and (ii) resources with a greater time-of-failure for the cycle time. These two methods are not considered in the scope of this work.

\section{Research method}

This article presents an experimental research strategy using the modeling and simulation method, since it permits the numerical evaluation of a model and gathers data to estimate the true characteristics of a model (Law \& Kelton, 2000). It follows the research steps given by the authors, which are presented below:

a. Formulate the problem and plan the study: Clear definition of the overall objectives of the study, performance measures, scope of the model and other initial parameters, as well as predict the amount of resources required;

b. Collect data and define a model: Collect data and information about the system and use them to specify operating procedures, parameters and include probability distributions for the random variables used in the model. The program should be only enough detailed, otherwise it could cost too much to program and execute;

c. Validate the model: Verify if the defined model corresponds to the actual system, involving people who are familiar with the operation and regularly interact with the decision makers. The adequacy of the probability distributions of random variables should be verified at this point; 
d. Construct a computer program and verify: Implement the model defined earlier in a general-purpose language or a specially designed simulation language;

e. Make pilot runs and validate: Validate the agreement of the model and test the sensitivity of its output executing pilot runs;

f. Design experiments: Decide what designs to simulate, if there are more than one For each alternative, define the initial conditions, length of warm-up and simulation runs, as well as the number of replications. To increase statistical precision, variance-reduction techniques may be used at this point;

g. Make production runs: Simulate the program, obtaining performance data on the system designs of interests;

h. Analyze output data: Analyze the output data using statistical techniques, aiming to build a confidence interval for a measure of performance for one system design or to decide which system performs best according to a specific measure;

i. Document, present, and implement results: Document the assumptions considered and the program itself.

In a general manner, the procedures followed in this research are in line with the steps recommended by Law \& Kelton (2000), described above.

The simulated production system follows all the concepts and the dynamics of a production line according to the S-DBR/MTA system and was based in Castro (2016), which was inspired by a real manufacturing flow shop environment, more specifically a wood frame production line located in Brazil. The data was first obtained by Castro (2016) through a series of interviews with the company's executives and visits to the factory. The author, which is also part of this work, supplied the raw data to this research. The data was masked in order to protect the company.

The wooden frames are composed by four frames, one board and one pen holder. In the simulation, eight different products were used, four sizes in two colors each. The production process consists in nine operations, which are carried out by nine different resources. The flowchart shown in Figure 4 presents this process. It should be noted that this is an I-plant according to the VATI classification (Srikanth, 2010).

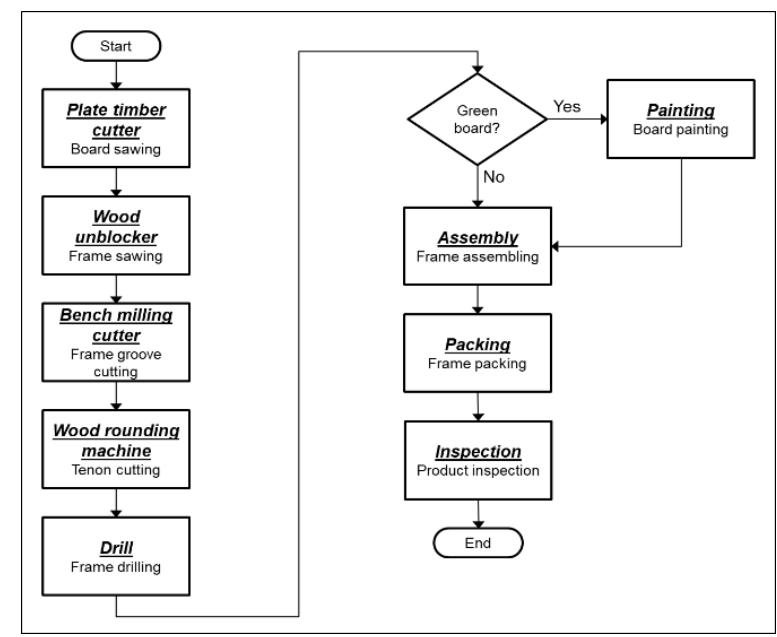

Figure 4. Wooden frames production process. Source: Adapted from Castro (2016).

The process consists in: 
- Board sawing: Plywood sheets are sawed according to the dimensions of the board;

- Frame sawing: Pinus clapboard are sawed to make the frames;

- Frame groove cutting: The grooves to assemble the board and the pen case are cut;

- Tenon cutting: Tenons are cut in both ends of the side frames to allow the assemble with the other ones;

- Frame drilling: Holes are drilled in the superior frame to fix the hooks to hang the frame;

- Board painting: The green boards are painted;

- Frame assembling: The board, the frames and the pen case are assembled;

- Frame packing: The frames are packed in plastic packages;

- Product inspection: Final inspection of the product.

Table 1 shows the initial mean processing times of all the resources for each product, given in hours. Such times must be understood as real mean processing times, considering the inefficiencies of the process. These times, however, were not modeled in order to distinguish the sources of variability and inefficiency.

The initial standard deviation is the product between the mean and the coefficient of variation 0,5. Therefore, it is a stochastic multiple mix model (Multi-Mixed Model Stochastic - MMS), in which multiple products are produced under the effect of variability (Pacheco et al., 2014).

Table 1. Initial mean processing times (hours). Source: Castro (2016).

\begin{tabular}{ccccccccc}
\hline & $\mathbf{8 1 6 4}$ & $\mathbf{8 1 6 6}$ & $\mathbf{8 1 6 7}$ & $\mathbf{8 1 6 8}$ & $\mathbf{8 1 7 5}$ & $\mathbf{8 1 7 7}$ & $\mathbf{8 1 7 8}$ & $\mathbf{8 1 8 0}$ \\
\hline Plate timber cutter & 0,0377 & 0,0440 & 0,0543 & 0,0770 & 0,0377 & 0,0440 & 0,0543 & 0,0770 \\
\hline Wood unblocker & 0,0462 & 0,0525 & 0,0525 & 0,0653 & 0,0462 & 0,0525 & 0,0525 & 0,0653 \\
\hline Bench milling cutter & 0,0500 & 0,0500 & 0,0500 & 0,0500 & 0,0500 & 0,0500 & 0,0500 & 0,0500 \\
\hline Wood rounding machine & 0,0462 & 0,0462 & 0,0462 & 0,0462 & 0,0462 & 0,0462 & 0,0462 & 0,0462 \\
\hline Drill & 0,0600 & 0,0600 & 0,0600 & 0,0600 & 0,0600 & 0,0600 & 0,0600 & 0,0600 \\
\hline Painting & 0,0000 & 0,0000 & 0,0000 & 0,0000 & 0,0621 & 0,1168 & 0,1291 & 0,2337 \\
\hline Assembly & 0,0491 & 0,0491 & 0,0561 & 0,0561 & 0,0491 & 0,0491 & 0,0561 & 0,0561 \\
\hline Packing & 0,0487 & 0,0422 & 0,0487 & 0,0548 & 0,0487 & 0,0422 & 0,0487 & 0,0548 \\
\hline Inspection & 0,0494 & 0,0494 & 0,0494 & 0,0494 & 0,0494 & 0,0494 & 0,0494 & 0,0494 \\
\hline
\end{tabular}

The simulation consisted in 72 periods (months) of 192 hours of production, adding up to 13,824 hours. The first 12 periods were used as warm-up, thus, their data were not considered in the analysis. The distribution used to generate the demand and processing time data was lognormal, since it is asymmetric with the long tail on the right and disregards negative values (Becker et al., 2013). In addition, empirical evidence is presented by Brown (1959) that this distribution is a good representation of demand for products and by Hillier (2013) for processing times.

At the end of each period, the software indicates a resource to be improved, according to the policy of each derivation. Once identified, its mean processing time and standard deviation are reduced by $1,66 \%$. In Derivation 3 , which improves all 
resources simultaneously, this factor is divided by 9 - number of resources in the system -, in order to maintain constant the relative workforce responsible for the improvements.

The priorities in the release of production orders to the shop floor and in the waiting line for resources to become available are determined by the order status according to the S-DBR/MTA method, which considers the difference between the target level and the actual number of parts in the Finished Goods Inventory (FGI) plus the orders that are still in the pipeline (work in progress). Those that are in the red zone have higher priority over the yellow ones, and these are preferred over the green ones.

The independent variables used in the simulation are demand and the different types of resource capacity configurations, such as balanced, unbalanced and the intensity of workloads on resources. Results were measured and assessed in terms of the dependent variables Fill Rate (FR) and average Cycle Time (CT).

Fill rate is the proportion of demand met directly from available inventory (Silver et al., 1998). Its objective is to measure the service level of the system, that is, the immediate availability from the stock of finished goods in terms of quantity and mix of products.

Cycle Time is the time counted from the consumption of a single unity of finished goods until its replenishment (Schragenheim et al., 2009). Along the simulation, the software measures the average cycle time. It also allows estimating the quantity of work in progress using the Little's Law (Hopp \& Spearman, 2000). It was used to measure the time the system takes to replenish the goods that have been sold.

As already mentioned, the simulation is composed of six scenarios for line configuration which aim to analyze the system in relation to the resource utilization rate, and five derivations to focus improvements plus another one with no improvements, which assess each scenario according to a different improvement approach.

The daily workloads in all the scenarios behave according to the Figure 5 and are detailed below. Also, this figure permits the comparison with the workloads used in Castro (2016), from which the data was taken.

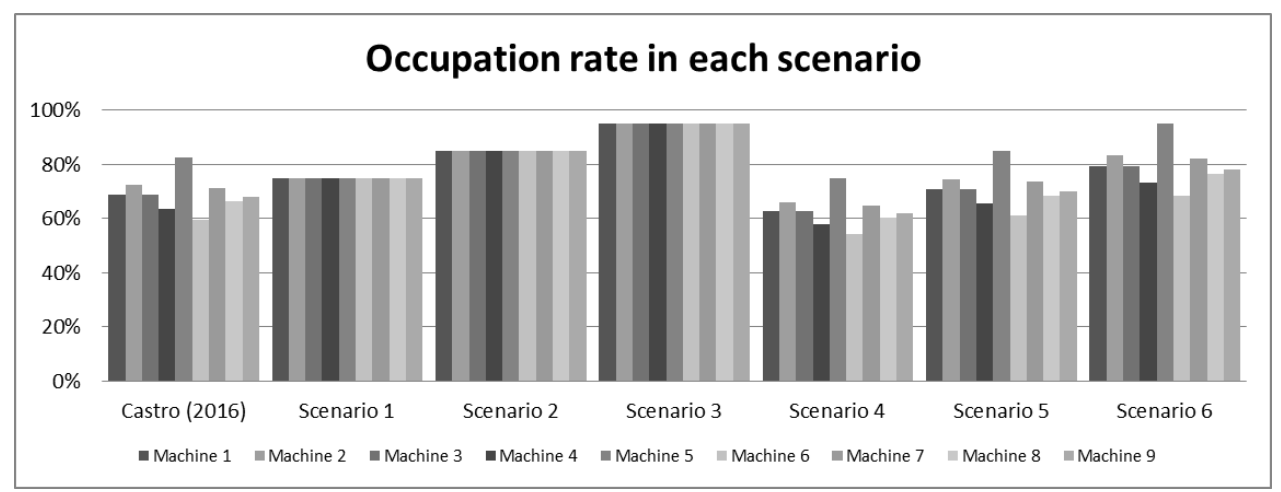

Figure 5. Occupation rate of the resources in the proposed scenarios.

Scenario 1 evaluates the behavior of improvements in a balanced system with low resource utilization. In it, the occupancy level of all resources was set at $75 \%$ of the work day, or 6 hours.

Scenario 2, as the previous one, assesses the system in a balanced environment, but with average occupancy rate. In this scenario, the occupancy level of all resources was set at $85 \%$ of the work day, or 6.8 hours. 
Scenario 3 also assesses the system in a balanced environment, but with a high occupancy level, set at $95 \%$ of the work day, or 7.6 hours.

Scenario 4 seeks to assess the behavior of the improvements in an unbalanced system with low occupation of the CCR. For this, the CCR occupancy level is $75 \%$ of the work day, or 6 hours, while the occupancy rate of the other resources were varied proportionally to it.

Scenario 5 simulates an unbalanced environment with average occupation of the CCR. In this case, the CCR occupancy level was set at $85 \%$ of the work day, or 6.8 hours, and the occupancy rate of the other resources varied in proportion to it.

Finally, Scenario 6 simulates an unbalanced environment with a high CCR occupancy level, $95 \%$ of the work day, or 7.6 hours.

The purpose of derivations is to analyze how different improvement policies affect the performance of the production system. The presence, in scenarios 4 to 6 , of protective capacity in the CCR is in line with the fundamental assumption of the S-DBR systems, that is, even the CCR must have sufficient protective capacity to be subordinated to the decisions to exploit the market constraint (Schragenheim et al., 2009). Protective capacity can be defined as "Resource capacity needed to protect the throughput of the system by ensuring that some capacity above the capacity required to exploit the constraint is available to catch up when disruptions inevitably occur" (Cox et al., 2012, p. 102).

The Derivations are shown below:

- Derivation 1: No improvements whatsoever. It works as a control so that the improvements made in the other scenarios can be compared with the absence of improvements;

- Derivation 2: Random resource improvements. In each period, the system randomly assigns a resource to be improved;

- Derivation 3: All resources improved at the end of each period. In order to maintain constant the workforce assigned to improvements, this method divides the impact by the number of resources;

- Derivation 4: Improvements based on the quantity of work in progress in each resource;

- Derivation 5: Highest utilization level in the previous period;

- Derivation 6: Quantity of orders that turn red at the end of each period, according to the Buffer Management method.

The simulation of the six scenarios with six derivations each aimed to increase the possibility of widespread results. Each combination was replicated 85 times and their results were measured in terms of Cycle Time (CT) and Fill Rate (FR).

The samples obtained were analyzed statistically using the software $R$, version 3.5.1, where the normality of the data was checked using the Shapiro-Wilk test (Shapiro \& Wilk, 1965) with a significance level of $5 \%$, which resulted in the non-normality of most of the experiments. This test was chosen because, according to Monte Carlo simulations of a small sample performed by Razali \& Wah (2011), there are evidences that, for a given significance level, it is more precise than other tests, such as Kolmogorov-Smirnov, Lilliefors e Anderson-Darling.

Considering the non-normality of most of the data, the Wilcoxon-Mann-Whitney test (Mann \& Whitney, 1947) with p-value adjustment given by Benjamini \& Hochberg (1995) with a 5\% significance level was used to compare the presence or absence of difference between the samples in pairs. 


\section{Results}

The analysis was based in the two dependent variables previously presented: Cycle Time (CT) and Fill Rate (FR). Firstly a descriptive analysis was made, observing the behavior of their means. Then, a test was performed to assess the normality of the data. Lastly, another test was made to assess the equality of the means between the members of each pair of derivations.

The mean CT is shown in Figure 6. In it, the lines represent the configuration scenarios of the line and the highlighted lines refer to the improvement policies imposed on each of them.

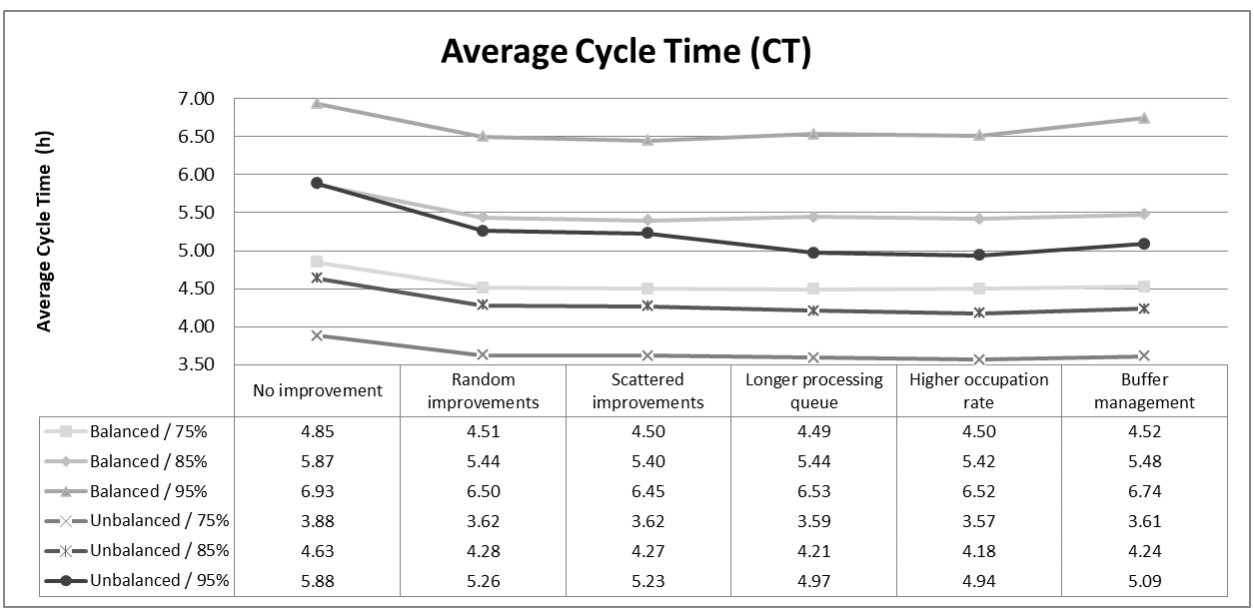

Figure 6. Average Cycle Time.

Analyzing the performance of the scenarios in relation to the improvement conditions, it is found that, in both balanced and unbalanced systems, the lower the system occupancy rate, the lower the CT. It is also found that for the same level of system occupancy, the unbalanced scenarios have lower average CT.

These two characteristics have a common cause: the amount of work in progress. In the first, the lesser occupation in the system permits that queues of items are not very long to process, which improves the flow of the parts. In the second, since there is only one constraint in the system and there is consequently less inventory needed to protect only one capacity constraint, flow is facilitated in relation to the corresponding one that has all of the resources with the same workloads.

In order to exemplify the behavior of the Cycle Time variable along the time, the scenario with $95 \%$ load was plotted and presented in Figure 7 . In it, the dashed lines refer to the balanced derivations while the continuous lines are the unbalanced derivations. Each line shows the behavior of a specific improvement method. 


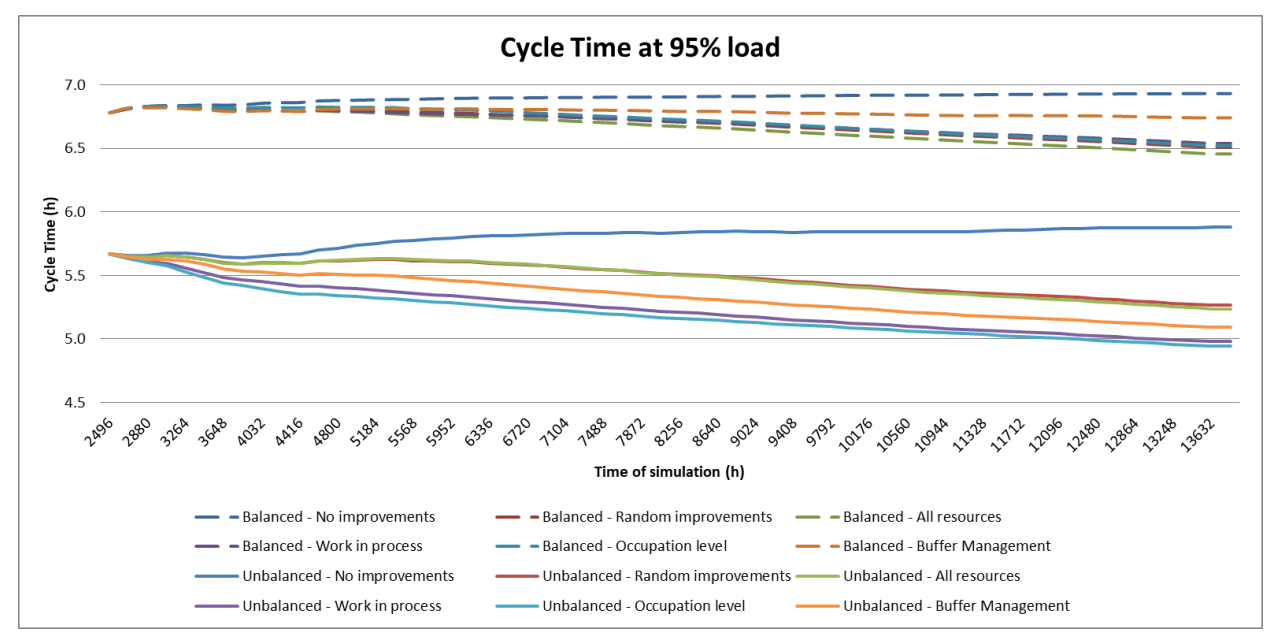

Figure 7. Cycle Time at $95 \%$ workload.

After the warm-up time ( 2.496 hours), unbalanced scenarios had better behavior in terms of cycle time than the ones with balanced system. Also, even the balanced scenario with the best improvement method has a worse result than the unbalanced scenario with no improvement. This fact endorses Goldratt's assertions that, when an unbalanced system is compared to a balanced system with the same capacity as the capacity-constrained resource, the first achieves shorter cycle time than the second.

It can be seen that an improvement made simultaneously in all resources, even with a fraction of the improvement factor, performed better in the balanced scenarios, while improvements focused on the resource with the highest occupation level had better performance in the unbalanced scenarios.

The same analysis was made to the variable Fill Rate, whose behavior is shown in Figure 8. Similar to the previous one, each line represents a scenario and each point highlighted shows an improvement policy.

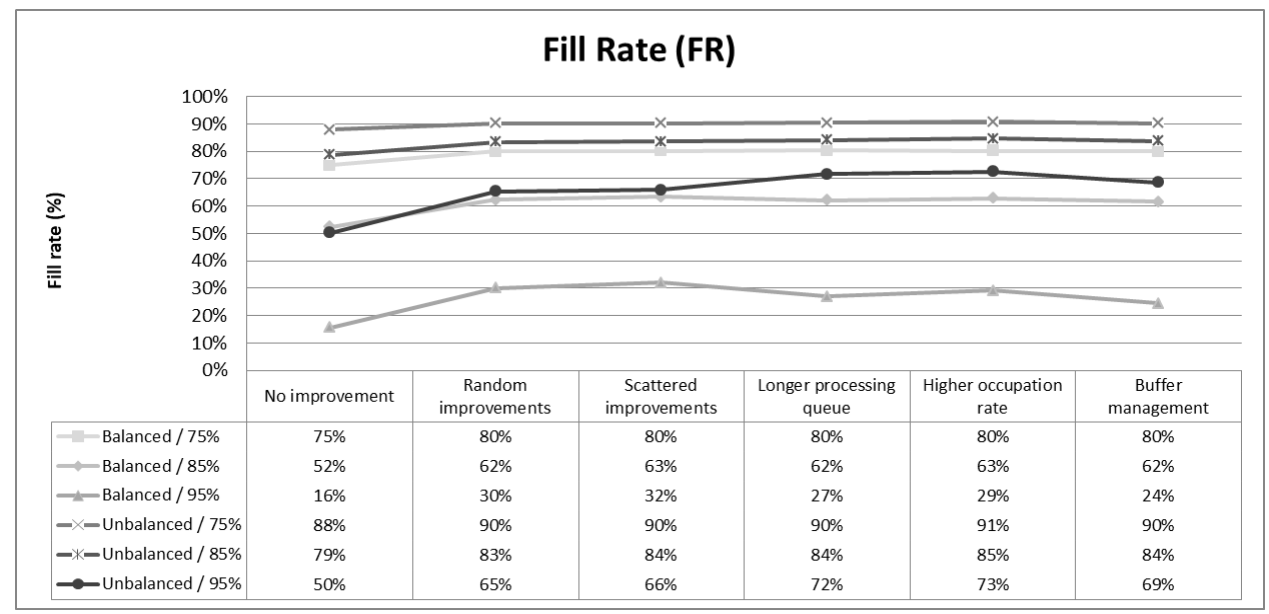

Figure 8. Fill Rate.

The behavior depicted resembles the inverse of the average cycle time: within each type of line configuration (balanced/unbalanced), the lower the system occupancy rate, 
the higher the FR. Likewise, when comparing the balanced/unbalanced pairs for each occupation level, the unbalanced scenarios performed better in terms of FR than the balanced ones.

Figure 9 shows the FR behavior along the time at $95 \%$ load. Again, the continuous lines refer to improvement policies made to the unbalanced scenarios while the dashed lines refer to improvement policies made to the balanced ones.

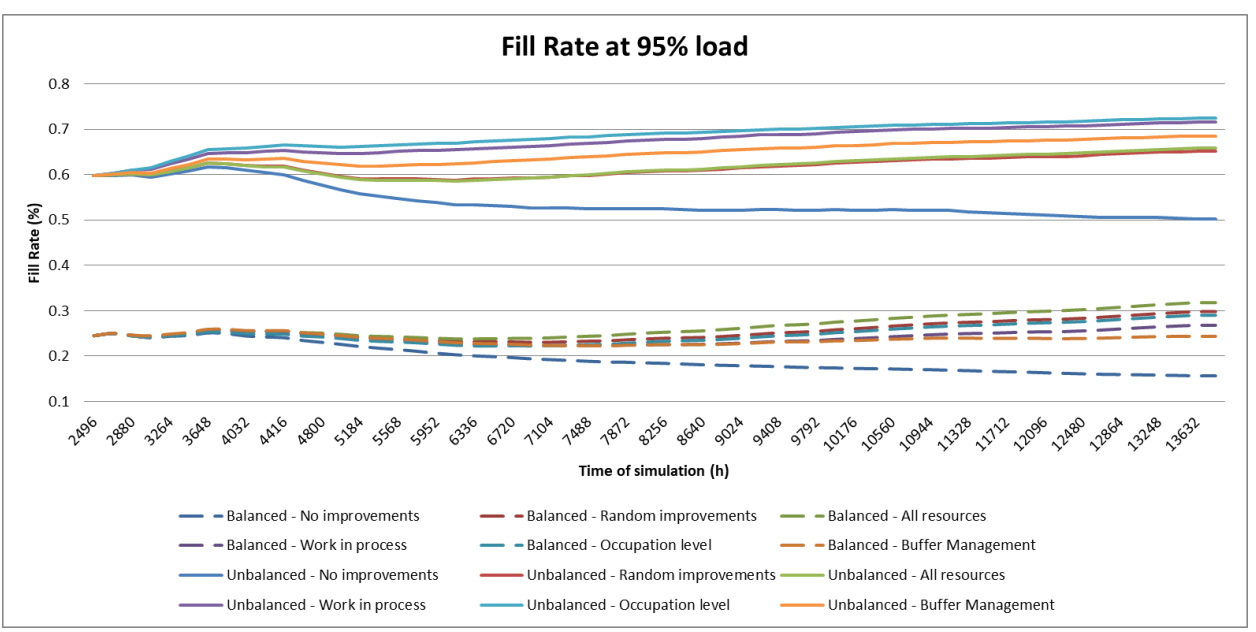

Figure 9. Fill Rate at 95\% workload.

Such as the variable previously addressed, unbalanced scenarios have results significantly superior when compared to the balanced scenarios. Again, all-resource improvement policy shows better results in balanced scenarios, while the highest occupation level improvement policy is the best option for unbalanced systems.

After the descriptive analysis, a Shapiro-Wilk normality test was conducted to assess the normality of the scenarios for each variable. As can be seen in Table 2, the test suggested that, for the CT variable, seven of the 36 scenarios had normal distribution ( $p$-value $>5 \%$ ), among which the six scenarios in configuration 4 are included. As per the FR variable, whose results are shown in Table 3, four of the 36 scenarios are normally distributed ( $p$-value $>5 \%$ ), all of them belonging to the fourth configuration.

Table 2. Normality test result for the variable CT.

\begin{tabular}{cccl}
\hline Scenario & W & p-value & Conclusion \\
\hline S1_D1 & 0.26833 & $2.2 \mathrm{E}-16$ & Non-normal \\
\hline S1_D2 & 0.28008 & $2.2 \mathrm{E}-16$ & Non-normal \\
\hline S1_D3 & 0.28334 & $2.2 \mathrm{E}-16$ & Non-normal \\
\hline S1_D4 & 0.72408 & $2.4 \mathrm{E}-11$ & Non-normal \\
\hline S1_D5 & 0.25272 & $2.2 \mathrm{E}-16$ & Non-normal \\
\hline S1_D6 & 0.77097 & $3.5 \mathrm{E}-10$ & Non-normal \\
\hline S2_D1 & 0.35089 & $2.2 \mathrm{E}-16$ & Non-normal \\
\hline S2_D2 & 0.35337 & $2.2 \mathrm{E}-16$ & Non-normal \\
\hline S2_D3 & 0.28785 & $2.2 \mathrm{E}-16$ & Non-normal \\
\hline S2_D4 & 0.32476 & $2.2 \mathrm{E}-16$ & Non-normal \\
\hline
\end{tabular}


Table 2. Continued...

\begin{tabular}{|c|c|c|c|}
\hline Scenario & $\mathbf{W}$ & $p$-value & Conclusion \\
\hline S2_D5 & 0.32926 & $2.2 \mathrm{E}-16$ & Non-normal \\
\hline S2_D6 & 0.35888 & $2.2 \mathrm{E}-16$ & Non-normal \\
\hline S3_D1 & 0.53020 & 4.7E-15 & Non-normal \\
\hline S3_D2 & 0.44666 & 2.6E-16 & Non-normal \\
\hline S3_D3 & 0.48765 & 1.0E-15 & Non-normal \\
\hline S3_D4 & 0.56087 & $1.5 \mathrm{E}-14$ & Non-normal \\
\hline S3_D5 & 0.56233 & 1.6E-14 & Non-normal \\
\hline S3_D6 & 0.43309 & $2.2 \mathrm{E}-16$ & Non-normal \\
\hline S4_D1 & 0.98542 & 4.6E-01 & Normal \\
\hline S4_D2 & 0.98465 & 4.1E-01 & Normal \\
\hline S4_D3 & 0.98224 & 2.9E-01 & Normal \\
\hline S4_D4 & 0.98795 & $6.2 \mathrm{E}-01$ & Normal \\
\hline S4_D5 & 0.98860 & 6.7E-01 & Normal \\
\hline S4_D6 & 0.97598 & 1.1E-01 & Normal \\
\hline S5_D1 & 0.79355 & 1.4E-09 & Non-normal \\
\hline S5_D2 & 0.96656 & 2.6E-02 & Non-normal \\
\hline S5_D3 & 0.97782 & $1.5 \mathrm{E}-01$ & Normal \\
\hline S5_D4 & 0.96986 & 4.4E-02 & Non-normal \\
\hline S5_D5 & 0.70662 & $9.7 \mathrm{E}-12$ & Non-normal \\
\hline S5_D6 & 0.97069 & 5.0E-02 & Non-normal \\
\hline S6_D1 & 0.80743 & 3.6E-09 & Non-normal \\
\hline S6_D2 & 0.72802 & 3.0E-11 & Non-normal \\
\hline S6_D3 & 0.58612 & $4.1 \mathrm{E}-14$ & Non-normal \\
\hline S6_D4 & 0.36925 & $2.2 \mathrm{E}-16$ & Non-normal \\
\hline S6_D5 & 0.36931 & $2.2 \mathrm{E}-16$ & Non-normal \\
\hline S6_D6 & 0.55649 & 1.3E-14 & Non-normal \\
\hline
\end{tabular}

Table 3. Normality test result for the variable FR.

\begin{tabular}{cccl}
\hline Scenario & W & p-value & Conclusion \\
\hline S1_D1 & 0.29773 & $2.2 \mathrm{E}-16$ & Non-normal \\
\hline S1_D2 & 0.34216 & $2.2 \mathrm{E}-16$ & Non-normal \\
\hline S1_D3 & 0.33022 & $2.2 \mathrm{E}-16$ & Non-normal \\
\hline S1_D4 & 0.78991 & $1.1 \mathrm{E}-09$ & Non-normal \\
\hline S1_D5 & 0.31209 & $2.2 \mathrm{E}-16$ & Non-normal \\
\hline S1_D6 & 0.75753 & $1.6 \mathrm{E}-10$ & Non-normal \\
\hline S2_D1 & 0.50328 & $1.8 \mathrm{E}-15$ & Non-normal \\
\hline S2_D2 & 0.41388 & $2.2 \mathrm{E}-16$ & Non-normal \\
\hline S2_D3 & 0.35435 & $2.2 \mathrm{E}-16$ & Non-normal \\
\hline S2_D4 & 0.39598 & $2.2 \mathrm{E}-16$ & Non-normal \\
\hline S2_D5 & 0.39019 & $2.2 \mathrm{E}-16$ & Non-normal \\
\hline S2_D6 & 0.40068 & $2.2 \mathrm{E}-16$ & Non-normal \\
\hline
\end{tabular}


Table 3. Continued...

\begin{tabular}{|c|c|c|c|}
\hline Scenario & $\mathbf{W}$ & p-value & Conclusion \\
\hline S3_D1 & 0.94992 & $2.4 \mathrm{E}-03$ & Non-normal \\
\hline S3_D2 & 0.74587 & 8.0E-11 & Non-normal \\
\hline S3_D3 & 0.76656 & 2.7E-10 & Non-normal \\
\hline S3_D4 & 0.87032 & 4.4E-07 & Non-normal \\
\hline S3_D5 & 0.82821 & 1.6E-08 & Non-normal \\
\hline S3_D6 & 0.87938 & $9.8 \mathrm{E}-07$ & Non-normal \\
\hline S4_D1 & 0.98473 & 4.2E-01 & Normal \\
\hline S4_D2 & 0.97186 & 6.0E-02 & Normal \\
\hline S4_D3 & 0.97269 & 6.8E-02 & Normal \\
\hline S4_D4 & 0.96374 & 1.7E-02 & Non-normal \\
\hline S4_D5 & 0.95843 & 7.9E-03 & Non-normal \\
\hline S4_D6 & 0.97233 & 6.4E-02 & Normal \\
\hline S5_D1 & 0.81767 & 7.3E-09 & Non-normal \\
\hline S5_D2 & 0.95972 & 9.5E-03 & Non-normal \\
\hline S5_D3 & 0.96246 & 1.4E-02 & Non-normal \\
\hline S5_D4 & 0.94196 & 8.2E-04 & Non-normal \\
\hline S5_D5 & 0.72313 & $2.3 E-11$ & Non-normal \\
\hline S5_D6 & 0.95957 & 9.3E-03 & Non-normal \\
\hline S6_D1 & 0.82494 & $1.2 \mathrm{E}-08$ & Non-normal \\
\hline S6_D2 & 0.65145 & $6.7 \mathrm{E}-13$ & Non-normal \\
\hline S6_D3 & 0.59224 & $5.2 \mathrm{E}-14$ & Non-normal \\
\hline S6_D4 & 0.42112 & $2.2 \mathrm{E}-16$ & Non-normal \\
\hline S6_D5 & 0.40346 & $2.2 \mathrm{E}-16$ & Non-normal \\
\hline S6_D6 & 0.55303 & 1.1E-14 & Non-normal \\
\hline
\end{tabular}

In order to show the results of both the variables together, it was also made a joint comparison between them, shown in Table 4, which assess the balanced scenarios (1, 2 and 3 ) and Table 5, which compares them in the unbalanced scenarios (4, 5 and 6$)$. Both tables show the best derivation for each pair, in both variables simultaneously. The "=" symbol means that there is no significant difference between the members of the pair being analyzed, indicated by the Wilcoxon-Mann-Whitney test and, therefore, the best one cannot be pinpointed. 
Table 4. Balanced scenarios.

\begin{tabular}{|c|c|c|c|c|c|c|}
\hline & \multicolumn{2}{|c|}{ Scenario 1 (75\% load) } & \multicolumn{2}{|c|}{ Scenario 2 (85\% load) } & \multicolumn{2}{|c|}{ Scenario 3 (95\% load) } \\
\hline & CT & FR & CT & FR & CT & FR \\
\hline D1 x D2 & D2 & D2 & D2 & D2 & D2 & D2 \\
\hline D1 x D3 & D3 & D3 & D3 & D3 & D3 & D3 \\
\hline D1 x D4 & D4 & D4 & D4 & D4 & D4 & D4 \\
\hline D1 x D5 & D5 & D5 & D5 & D5 & D5 & D5 \\
\hline D1 x D6 & D6 & D6 & D6 & D6 & D6 & D6 \\
\hline D2 x D3 & D3 & $=$ & D3 & $=$ & D3 & D3 \\
\hline D2 x D4 & $=$ & $=$ & D2 & $=$ & D2 & D2 \\
\hline D2 x D5 & D5 & $=$ & D5 & $=$ & $=$ & $=$ \\
\hline D2 x D6 & D2 & D2 & D2 & D2 & D2 & D2 \\
\hline D3 x D4 & D3 & $=$ & D3 & D3 & D3 & D3 \\
\hline D3 x D5 & $=$ & $=$ & $=$ & $=$ & D3 & D3 \\
\hline D3 x D6 & D3 & D3 & D3 & D3 & D3 & D3 \\
\hline D4 x D5 & $=$ & $=$ & D5 & D5 & D5 & D5 \\
\hline D4 x D6 & D4 & $=$ & D4 & $=$ & D4 & D4 \\
\hline D5 x D6 & D5 & D5 & D5 & D5 & D5 & D5 \\
\hline
\end{tabular}

As can be seen in Scenario 1, when there is a significant difference between the derivations of each pair, the same derivation always seems to be the best in both variables. It can be concluded that, for the CT variable, derivations 3 and 5 appear to be the best, but this cannot be said for the FR variable, in which there is no difference between Derivations 2, 3, 4 and 5 .

The joint comparison of Scenario 2 shows the same behavior as described in the previous one, since Derivations 3 and 5 also show the best results in terms of CT and Derivations 2, 3, 4 and 5, in terms of FR.

In Scenario 3, Derivation 3 (dispersed improvements in all resources) stands out, showing the best performance for both $\mathrm{CT}$ and the FR indicators.

Table 5 shows the results of both variables for the unbalanced scenarios $(4,5$ and 6). Again, the "=" symbol shows that there is no significant difference between the members of the pair being analyzed, indicated by the Wilcoxon-Mann-Whitney test.

Table 5. Unbalanced scenarios.

\begin{tabular}{|c|c|c|c|c|c|c|}
\hline & \multicolumn{2}{|c|}{ Scenario 4 (75\% load) } & \multicolumn{2}{|c|}{ Scenario 5 (85\% load) } & \multicolumn{2}{|c|}{ Scenario 6 (95\% load) } \\
\hline & $\mathrm{CT}$ & FR & CT & FR & CT & FR \\
\hline D1 x D2 & D2 & D2 & D2 & D2 & D2 & D2 \\
\hline D1 x D3 & D3 & D3 & D3 & D3 & D3 & D3 \\
\hline D1 x D4 & D4 & D4 & D4 & D4 & D4 & D4 \\
\hline
\end{tabular}


Table 5. Continued...

\begin{tabular}{|c|c|c|c|c|c|c|}
\hline \multirow[b]{2}{*}{ D1 x D5 } & \multicolumn{2}{|c|}{ Scenario 4 (75\% load) } & \multicolumn{2}{|c|}{ Scenario 5 (85\% load) } & \multicolumn{2}{|c|}{ Scenario 6 (95\% load) } \\
\hline & D5 & D5 & D5 & D5 & D5 & D5 \\
\hline D1 x D6 & D6 & $\mathrm{D} 6$ & D6 & D6 & D6 & D6 \\
\hline D2 x D3 & $=$ & $=$ & D3 & $=$ & $=$ & $=$ \\
\hline D2 x D4 & D4 & $=$ & D4 & D4 & D4 & D4 \\
\hline D2 x D5 & D5 & D5 & D5 & D5 & D5 & D5 \\
\hline D2 $\times$ D6 & $=$ & $=$ & D6 & D6 & D6 & D6 \\
\hline D3 x D4 & D4 & $=$ & D4 & D4 & D4 & $\mathrm{D} 4$ \\
\hline D3 x D5 & D5 & D5 & D5 & D5 & D5 & D5 \\
\hline D3 $\times$ D6 & $=$ & $=$ & D6 & $=$ & D6 & D6 \\
\hline D4 x D5 & D5 & D5 & D5 & D5 & D5 & D5 \\
\hline D4 x D6 & D4 & $=$ & D4 & D4 & D4 & D4 \\
\hline D5 $\times$ D6 & D5 & D5 & D5 & D5 & D5 & D5 \\
\hline
\end{tabular}

In Scenario 4, the variables show the same behavior in cases where there is significant difference. In this case, it is possible to state that Derivation 5 (improvements focused on resources with greater level of use) shows the best performance in both variables analyzed. Derivation 4 (improvement focused on the resources that have the largest queues) has the second best result.

Scenario 5 has similar results as the previous one, with Derivation 5 showing the best results, with the lowest CT and the highest FR, followed by Derivation 4 .

Finally, the variables in Scenario 6 behave similarly as the previous cases. In this case, Derivation 6 has the third best result.

\section{Discussion}

The objective of this article was to assess, in a production control S-DBR/MTA, six improvement strategies, including three recommended by TOC, in six production line configurations, three of which balanced and three have a significant difference in occupation rate between the CCR and the other resources.

It was found that, when there is significant difference, the behavior of variables $C T$ and FR is similar. All pairs have the same derivations as the best ones for both variables, within balanced and unbalanced scenarios. This fact shows that the improvement strategies impact CT and FR in a relatively similar manner.

In the balanced scenario with a low level of resource utilization, it is not possible to conclude which improvement method performs best. In the high load balanced scenario, however, it is possible to conclude that Derivation 3 obtains the best result. In the case of unbalanced scenarios, the result was quite solid, with Derivation 5 always being better than the others, followed by Derivation 4 , in whichever workloads applied to the system.

The result obtained for the balanced scenario is justified by the fact that, by definition, all resources have the same workload and, therefore, it is necessary to improve all of them simultaneously in order to obtain an overall impact in terms of lower CT and higher 
FR. Improvements spread across all plant resources seem to align with the assumptions of a balanced line, in which maximizing the use of all resources becomes a prerequisite and a justification for its adoption (Pacheco et al., 2014). It is important to note that, although the improvement method identified here is not recommended by TOC, the improvements occurred in a non-TOC (balanced) environment.

\subsection{Theoretical implications}

According to Davis et al. (2007), theoretical contribution is one of the main criteria to be evaluated in order to develop theory using simulation methods. It is, as the authors state, determined by the quality of the research question based on the literature and the quality of experimentation. The other criterion to be considered is strength of method, which includes the clear justification for using simulation and an accurate computational representation of the logic analyzed.

The main theoretical implication of this work relies on the contributions of Theory of Constraints' methods of capacity-constrained resource identification to the continuous improvement. This work, using a quantitative analysis, showed that the method of identification that considers the utilization level of the resources generated better results than the other ones.

The result obtained for the unbalanced scenarios are also in line with the literature, since the improvement approaches with better performances in these cases focus on a specific machine (Goldratt \& Cox, 2014; Pacheco et al., 2014). Therefore, the best improvement methods are recommended by TOC and were applied in a TOC (unbalanced) environment.

This research gives another insight on the method that yields the most benefits to improve the throughput of a flow shop production system, contributing to a strict range of works, such as Godinho \& Uzsoy (2014), Godinho \& Utiyama (2015) and Wu et al. (2020).

The results agree with the findings made by Godinho \& Utiyama (2015), as both works conclude that, to improve balanced lines, simultaneous improvements made along the line bring should be done, and for unbalanced lines with a significant difference between cycle times of CCR and non-CCR resources, focused improvements should be done. The authors also state that, when big investments cannot be made, one should choose a hybrid option, prioritizing actions in all the upstream resources, including the CCR.

Godinho \& Uzsoy (2014) and Wu et al. (2020) are also in line with the findings of this study. Although they find that improvements in some non-CCR resources yields better results than in the CCR, these improvements aim to lower the variability in the upstream resources, which may positively affect the CCR's output.

Finally, the research also showed that the Buffer Management method does not yield the best results, which is somewhat surprising. One possible explanation is that the variability of upstream resources may have affected the stations in which the red orders appeared, causing them to lose too much time in previous stations and actually turning red in the CCR. Despite this, the BM is the recommended technique to stablish a focused flow balancing (continuous improvement) and is still a good way to identify the resource that needs improvement, confirming the theory presented by Schragenheim (2010). 


\subsection{Managerial implications}

The practical implications of the research rely on the fact that manufacturing engineering should prefer unbalanced production lines, with some excess capacity even in the capacity-constrained resource, and improve them avoiding balancing them.

Another positive aspect in having unbalanced lines is that the workforce assigned to resource improvement can focus efforts in one resource at a time (the capacityconstrained), usually requiring less time to execute improvements, compared to balanced lines in which, in order to have global improvement, it is required to improve all resources at once. As the findings showed, in order to identify the resource that needs to be improved, managers should use the utilization level data usually supplied by the company's ERP (Enterprise Resource Planning).

The interpretation of the results achieved should be taken carefully, as it does not emulate the intuitions and technical knowledge of the people involved in the decision making process.

\section{Conclusions}

The aim of this research was to assess different ways of improving production resources using computer simulation. The approaches to improvements analyzed were: improvements in resources chosen randomly, improvements in all resources simultaneously, prioritization by the size of the processing queue, prioritization by utilization level, and prioritization by the Buffer Management method. In addition to these, as a form of control, a derivation without improvements was also included. The simulation took place in six production systems with different occupancy levels, being three balanced and three unbalanced.

From the results, it can be concluded that the same improvement strategy cannot be used for balanced and unbalanced systems. In balanced systems, the strategy of dispersed improvements, improving all the resources simultaneously, obtained the best performances both in terms of CT and FR. As such, the whole system is impacted by the improvements. If a single link of this type were improved in the system, the improvement would only impact that link and the system would continue to be constrained by the other resources.

In unbalanced systems, on the other hand, it is possible to have an improvement approach that focuses on the constrained resource, either by monitoring the occupation of each machine individually, by checking the queues that form before resources, or by using the Buffer Management method for production control. As such, the system automatically pinpoints the resource that mostly contributes to the obstruction in the production flow. This study points out, in a pioneering manner, that the strategy of choosing the resources to be improved based on the utilization level is better than the others in unbalanced make to stock environments.

The result shows, in practical terms, that managers could plan and keep unbalanced production systems without bottleneck resources (market constraint) and, in these cases, improvements must be focused in the capacity constrained resource.

This research has contributed to the literature of TOC, more specifically to Buffer Management and S-DBR/MTA methods and its vision of continuous improvement process. The quantitative research used in this paper is pioneer and can be used as a starting point to others researches that interface the themes TOC and continuous improvement. 
The improvement strategies evaluated in the present work were extracted from the TOC literature, as well as the environment in which they were simulated emulates the S-DBR/MTA method, also from TOC. Future research could investigate and compare other improvement strategies, as well as comparing them according to different production planning and control systems, such as MRP (material requirement planning), JIT (just in time) and CONWIP (Constant Work in Process). Such research could contribute and advance the frontiers of knowledge of the literature that compares different production planning and control systems, such as Gupta \& Snyder (2009).

The research is limited by the scenarios, derivations and variables used, and the fact that no other player in the supply chain was considered. Other variables can be assessed in future studies, such as the inclusion of machine down or other sources of variability and inefficiency, as, for example, modeling suggested in Kim, Cox \& Mabin (2010). Another opportunity of continuing research is to include the costs or investments in capacity of the stations as Godinho \& Barco (2015) and Wu et al. (2020). Others can address the same issue, in a more complex system or in a make-to-order production environment.

This research may also benefit companies that develop or are users of automotive technology or data analysis systems, since the methods of identification of resources to be improved can be automated, showing in real time the situation of the resources, such as their utilization levels, their work in progress waiting for processing and their buffer status, assisting the decision-making made by managers.

It is also worth noting that the present research did not intend to measure the production flow directly, focusing on service level indicators to meet demand. Thus, different results could be obtained if the best improvement strategies were chosen due to the higher observed flow.

\section{Acknowledgements}

We thank the entire Theory of Constraints research group at São Paulo State University for their contributions to this work.

\section{References}

Barnard, A. (2010). Continuous improvement and auditing. In J. F. Cox III \& J. G. Schleier (Eds.), Theory of Constraints Handbook (pp. 413-468). New York, NY: McGraw-Hill.

Becker, J., Hartmann, W., Bertsch, S., Nywlt, J., \& Schmidt, M. (2013). Dynamic safety-stock calculation. International Journal of Mechanical, Industrial Science and Engineering, 7(10), 781-785.

Benavides, M. B., \& Van Landegheim, H. (2015). Implementation of S-DBR in four manufacturing SMEs: a research case study. Production Planning \& Control: The Management of Operations, 26(13), 1110-1127. http://dx.doi.org/10.1080/09537287.2015.1015060.

Benjamini, Y., \& Hochberg, Y. (1995). Controlling the false discovery rate: a practical and powerful approach to multiple testing. Journal of the Royal Statistical Society. Series A, 57(1), 289-300.

Brown, R. G. (1959). Statistical forecasting for inventory control. New York, NY: McGraw-Hill.

Castro, R. F. (2016). Evaluation of Simplified Drum-Buffer-Rope system in make to stock environments (Master's thesis). Sao Paulo State University, Bauru. 
Chakravorty, S. S., \& Atwater, J. B. (2006). Bottleneck management: theory and practice. Production Planning and Control, 17(5), 441-447. http://dx.doi.org/10.1080/09537280600682752.

Chakravorty, S. S., \& Hales, D. N. (2016). Improving labor relations performance using a Simplified Drum Buffer Rope (S-DBR) technique. Production Planning \& Control: The Management of Operations, 27(2), 102-113. http://dx.doi.org/10.1080/09537287.2015.1079744.

Chang, Y. C., \& Huang, W. T. (2011a). A modification of Simplified Drum-Buffer-Rope for reentrant flow shop scheduling. Information Technology Journal, 10(1), 40-50. http://dx.doi.org/10.3923/itj.2011.40.50.

Chang, Y. C., \& Huang, W. T. (2011b). Using simplified drum-buffer-rope for re-entrant flow shop scheduling in a random environment. African Journal of Business Management, 5(26), 10796-10810.

Chang, Y. C., \& Huang, W. T. (2014). An enhanced model for SDBR in a random reentrant flow shop environment. International Journal of Production Research, 52(6), 1808-1826. http://dx.doi.org/10.1080/00207543.2013.848491.

Cox, J. F. 3rd, Boyd, L. H., Sullivan, T. T., Reid, R. A., \& Cartier, B. (2012). The Theory of Constraints International Certification Organization Dictionary. 2nd ed. New York, NY: McGraw-Hill.

Davis, J. P., Eisenhardt, K. M., \& Bingham, C. B. (2007). Developing theory through simulation methods. Academy of Management Review, 32(2), 480-499. http://dx.doi.org/10.5465/amr.2007.24351453.

Gardiner, S. C., Blackstone, J. H. Jr, \& Gardiner, L. R. (1993). Drum-Buffer-Rope and Buffer Management: impact on production management study and practices. International Journal of Operations \& Production Management, 13(6), 68-78. http://dx.doi.org/10.1108/01443579310039047.

Godinho, M. Fo., \& Barco, C. F. (2015). A framework for choosing among different lean-based improvement programs. International Journal of Advanced Manufacturing Technology, 81(1-4), 183-197. http://dx.doi.org/10.1007/s00170-015-7181-4.

Godinho, M. Fo., \& Utiyama, M. H. R. (2015). Comparing different strategies for the allocation of improvement programmes in a flowshop environment. International Journal of Advanced Manufacturing Technology, 77(5-8), 1365-1385. http://dx.doi.org/10.1007/s00170-0146553-5.

Godinho, M. Fo., \& Utiyama, M. H. R. (2016). Comparing the effect of different strategies of continuous improvement programmes on repair time to reduce lead time. International Journal of Advanced Manufacturing Technology, 87(1-4), 315-327. http://dx.doi.org/10.1007/s00170-016-8483-x.

Godinho, M. Fo., \& Uzsoy, R. (2011). The effect of shop floor continuous improvement programs on the lot size-cycle time relation-ship in a multi-product single-machine environment. International Journal of Advanced Manufacturing Technology, 52(5-8), 669681. http://dx.doi.org/10.1007/s00170-010-2770-8.

Godinho, M. Fo., \& Uzsoy, R. (2013). The impact of simultaneous continuous improvement in setup time and repair time on manufacturing cycle times under uncertain conditions. International Journal of Production Research, 51(2), 447-464. http://dx.doi.org/10.1080/00207543.2011.652261.

Godinho, M. Fo., \& Uzsoy, R. (2014). Assessing the impact of alternative continuous improvement programmes in a flow shop using system dynamics. International Journal of Production Research, 52(10), 3014-3031. http://dx.doi.org/10.1080/00207543.2013.860249.

Goldratt, E. M. (1990). The haystack syndrome: sifting information out of the data ocean. New York, NY: North River Press. 
Goldratt, E. M. (2009). Standing on the shoulders of giants: production concepts versus production applications: The Hitachi Tool Engineering example. Gestão \& Produção, 16(3), 333-343. http://dx.doi.org/10.1590/S0104-530X2009000300002.

Goldratt, E. M. (2010). Introduction to TOC - my perspective. In J. F. Cox III \& J. G. Schleier (Eds.), Theory of constraints handbook (pp. 3-9). New York, NY: McGraw-Hill.

Goldratt, E. M., \& Cox, J. (2014). The goal. New York, NY: North River Press.

Goldratt, E. M., \& Fox, R. E. (1986). The race. New York, NY: North River Press.

Gupta, M., \& Snyder, D. (2009). Comparing TOC with MRP and JIT: a literature review. International Journal of Production Research, 47(13), 3705-3739. http://dx.doi.org/10.1080/00207540701636322.

Hammer, M., \& Champy, J. (2002). Reengineering the corporation: a manifesto for business revolution. New York, NY: Perfect Bound.

Hillier, M. (2013). Designing unpaced production lines to optimize throughput and work-inprocess inventory. IIE Transactions, 45(5), 516-527. http://dx.doi.org/10.1080/0740817X.2012.706733.

Hinckeldeyn, J., Dekkers, R., Altfeld, N., \& Kreutzfeldt, J. (2014). Expanding bottleneck management from manufacturing to product design and engineering processes. Computers \& Industrial Engineering, 76, 415-428. http://dx.doi.org/10.1016/j.cie.2013.08.021.

Hopp, W. J., \& Spearman, M. L. (2000). Factory physics. 2nd ed. New York: Mc-Graw-Hill.

Hopp, W. J., \& Spearman, M. L. (2004). To pull or not to pull: what is the question?. Manufacturing \& Service Operations Management: M \& SOM, 6(2), 133-148. http://dx.doi.org/10.1287/msom.1030.0028.

Ikeziri, L. M., Souza, F. B., Gupta, M. C., \& Fiorini, P. C. (2018). Theory of constraints: review and bibliometric analysis. International Journal of Production Research, 57(15-16), 50685102. http://dx.doi.org/10.1080/00207543.2018.1518602.

Imai, M. (1986). Kaizen:the key to Japan's competitive success. New York, NY: McGraw-Hill.

Kasemset, C., \& Kachitvichyanukul, V. (2010). Effect of confidence interval on bottleneck identification via simulation. In Proceedings of the IEEE International Conference on Industrial Engineering and Engineering Management (pp. 1592-1595). Macao, China: IEEE Industrial Engineering and Engineering Management. http://dx.doi.org/10.1109/IEEM.2010.5674275.

Kim, S., Cox, J. F., \& Mabin, V. J. (2010). An exploratory study of protective inventory in a reentrant line with protective capacity. International Journal of Production Research, 48(14), 4153-4178. http://dx.doi.org/10.1080/00207540902991666.

Kuo, T. C., Chang, S. H., \& Huang, S. N. (2009). Due-date performance improvement using TOC's aggregated time buffer method at a wafer fabrication factory. Expert Systems with Applications, 36(2), 1783-1792. http://dx.doi.org/10.1016/j.eswa.2007.12.038.

Kurdve, M., Sjögren, P., Gåsvaer, D., Widfeldt, M., \& Wiktorsson, M. (2016). Production system change strategy in lightweight manufacturing. In Proceedings of the 26th CIRP Design Conference (pp.160-165). Stockholm, Sweden: Elsevier Procedia. http://dx.doi.org/10.1016/j.procir.2016.04.137.

Law, A. M., \& Kelton, W. D. (2000). Simulation modeling and analysis. New York, NY: McGrawHill.

Lee, J. H., Chang, J. G., Tsai, C. H., \& Li, R. K. (2010). Research on enhancement of TOC Simplified Drum-Buffer-Rope system using novel generic procedures. Expert Systems with Applications, 37(5), 3747-3754. http://dx.doi.org/10.1016/j.eswa.2009.11.049. 
Li, J., Papadopoulos, C. T., \& Zhang, L. (2016). Continuous improvement in manufacturing and service systems. International Journal of Production Research, 54(21), 6281-6284. http://dx.doi.org/10.1080/00207543.2016.1228235.

Mann, H. B., \& Whitney, D. R. (1947). On a test of whether one of two random variables is stochastically larger than the other. Annals of Mathematical Statistics, 18(1), 50-60. http://dx.doi.org/10.1214/aoms/1177730491.

Pacheco, D. A. J., Lacerda, D. P., Corcini Neto, S. L. H., Jung, C. F., \& Antunes Júnior, J. A. V. (2014). Balanceamento de fluxo ou balanceamento de capacidade? análises e proposições sistêmicas. Gestão \& Produção, 21(2), 355-368. http://dx.doi.org/10.1590/S0104-530X2014005000006.

Pyzdek, T. (2003). The Six Sigma handbook. New York, NY: McGraw-Hill.

Razali, N. M., \& Wah, Y. B. (2011). Power comparisons of Shapiro-Wilk, Kolmogorov-Smirnov, Lilliefors and Anderson-Darling tests. Journal of Statistical Modeling and Analytics, 2(1), 21-33.

Reid, R. A. (2007). Applying the TOC five-step focusing process in the service sector. Managing Service Quality, 17(2), 209-234. http://dx.doi.org/10.1108/09604520710735209.

Roser, C., Nakano, M., \& Tanaka, M. (2002). Shifting bottleneck detection. In Proceedings of the Winter Simulation Conference (pp. 1079-1086). San Diego, CA: Winter Simulation Conference. http://dx.doi.org/10.1109/WSC.2002.1166360.

Schragenheim, E. M. (2010). Managing make-to-stock and the concept of make-to-availability. In J. F. Cox III \& J. G. Schleier (Eds.), Theory of Constraints Handbook (pp. 239-264). New York, NY: McGraw-Hill.

Schragenheim, E. M., \& Dettmer, H. W. (2001). Manufacturing at warp speed: optimizing supply chain financial performance. Boca Raton, FL: St. Lucie Press.

Schragenheim, E. M., \& Ronen, B. (1991). Buffer management: a diagnostic tool for production control. Production and Inventory Management Journal, 32(2), 74-79.

Schragenheim, E. M., Dettmer, H. W., \& Patterson, J. W. (2009). Supply Chain Management at warp speed: integrating the system from end to end. Boca Raton, FL: Taylor \& Francis. http://dx.doi.org/10.1201/9781420073362.

Schroeder, D. M., \& Robinson, A. G. (2017). America's most successful export to Japan: continuous improvement programs. Retrieved in January 27, 2017, from http://sloanreview. mit.edu/article/americas-most-successful-export-to-japan-continuous-improvementprograms

Shapiro, S. S., \& Wilk, M. B. (1965). An analysis of variance test for normality (complete samples). Biometrika, 52(3-4), 591-611. http://dx.doi.org/10.1093/biomet/52.3-4.591.

Silver, E., Pyke, D. F., \& Peterson, R. (1998). Inventory management and production planning and scheduling. New York: Wiley.

Slack, N., Chambers, S., \& Johnston, R. (2009). Operations management. New York, NY: Prentice Hall.

Souza, F. B., \& Baptista, H. R. (2010). Proposta de avanço para o método Tambor-PulmãoCorda Simplificado aplicado em ambientes de produção sob encomenda. Gestão \& Produção, 17(4), 735-746. http://dx.doi.org/10.1590/S0104-530X2010000400008.

Souza, F. B., \& Pires, S. R. I. (1999). Análise e proposições sobre o balanceamento e uso de excesso de capacidade em recursos produtivos. Gestão \& Produção, 6(2), 111-126. http://dx.doi.org/10.1590/S0104-530X1999000200004.

Souza, F. B., \& Pires, S. R. I. (2014). Produzindo para disponibilidade: uma aplicação da Teoria das Restrições em ambientes de produção para estoque. Gestão \& Produção, 21(1), 65-76. http://dx.doi.org/10.1590/S0104-530X2013005000007.

Souza, F. B., Rentes, A. F., \& Agostinho, O. L. (2002). A interdependência entre sistemas de controle de produção e critérios de alocação de capacidades. Gestão \& Produção, 9(2), 215-234. http://dx.doi.org/10.1590/S0104-530X2002000200008. 
Srikanth, M. (2010). DBR, Buffer Management, and VATI Flow Classification. In J. F. Cox III \& J. G. Schleier (Eds.), Theory of Constraints Handbook (pp. 175-210). New York, NY: McGraw-Hill.

Stratton, R., \& Knight, A. (2010). Managing patient flow using time buffers. Journal of Manufacturing Technology Management, 21(4), 484-498. http://dx.doi.org/10.1108/17410381011046599.

Umble, M., \& Umble, E. (2006). Utilizing buffer management to improve performance in a healthcare environment. European Journal of Operational Research, 174(2), 1060-1075. http://dx.doi.org/10.1016/j.ejor.2005.02.059.

Umble, M., Umble, E., \& Murakami, S. (2006). Implementing theory of constraints in a traditional Japanese manufacturing environment: the case of Hitachi Tool Engineering. International Journal of Production Research, 44(10), 1863-1880. http://dx.doi.org/10.1080/00207540500381393.

Wang, J., Chen, J., Wang, S., Zhang, Y., \& Sun, S. (2011). Shifting economic bottleneck identification. In Proceedings of the IEEE International Conference on Industrial Engineering and Engineering Management (pp. 1760-1764). Singapore, Singapore: IEEE Industrial Engineering and Engineering Management. http://dx.doi.org/10.1109/IEEM.2011.6118218.

White, T., Sengupta, S., \& Van Til, R. P. (2012). A new way to find bottlenecks. Industrial Engineering (American Institute of Industrial Engineers), 44(11), 45-49.

Womack, J. P., Jones, D. T., \& Roos, D. (1990). The machine that changed the world. New York, NY: McMillan.

Wu, K., Zheng, M., \& Shen, Y. (2020). A generalization of the Theory of Constraints: choosing the optimal improvement option with consideration of variability and costs. IISE Transactions, 52(3), 276-287. http://dx.doi.org/10.1080/24725854.2019.1632503. 


\title{
ERRATUM: Analysis of production resources improvement strategies in make-to-stock environments managed by the simplified drum-buffer-rope system
}

\author{
Humberto Govoni ${ }^{1}$ (D), Fernando Bernardi de Souza ${ }^{1}$ (D), Robson Flávio Castro ${ }^{2}$ (D), \\ José de Souza Rodrigues ${ }^{1}$ (D), Silvio Roberto Ignacio Pires ${ }^{3}$ (D) \\ Universidade Estadual Paulista, Departamento de Engenharia de Produção, Bauru, SP, Brasil. E-mail:
humberto.govoni@unesp.br; fernando.bernardi@unesp.br; jose.rodrigues@unesp.br
${ }^{2}$ Universidade Federal de São Carlos, Departamento de Engenharia de Produção, São Carlos, SP, Brasil. E-mail:
robson.castro@ufscar.br
${ }^{3}$ Fundação Getúlio Vargas, Departamento de Administração, Rio de Janeiro, RJ, Brasil. E-mail: sripires@fgvmail.br
}

Due to author's honest mistake the article "Analysis of production resources improvement strategies in make-to-stock environments managed by the simplified drum-buffer-rope system" (https://doi.org/10.1590/1806-9649-2021v28e55), published in Gestão \& Produção, 28(4), e55, was published with errors.

On page 27, where the text reads:

Goldratt, E. M. (2009). Standing on the shoulders of giants: production concepts versus production applications: The Hitachi Tool Engineering example. Project Management Journal, 16(3), 333-343.

It should read:

Goldratt, E. M. (2009). Standing on the shoulders of giants: production concepts versus production applications: The Hitachi Tool Engineering example. Gestão \& Produção, 16(3), 333-343. http://dx.doi.org/10.1590/S0104-530X2009000300002.

On page 28, where the text reads:

Pacheco, D. A. J., Lacerda, D. P., Corcini, S. L. H. No., Jung, C. F., \& Antunes, J. A. V. Jr. (2014). Flow balancing or capacity balancing? Systemic analysis and propositions. Project Management Journal, 21(2), 355-367.

Souza, F. B., \& Baptista, H. R. (2010). Proposal of enhancement for the Simplified Drum-Buffer- Rope method applied to make-to-order production environments. Project Management Journal, 17(4), 735-746.

Souza, F. B., \& Pires, S. R. I. (1999). Analysis and propositions about the balancing and use of over capacity in productive resources. Project Management Journal, 6(2), 111-126.

Souza, F. B., \& Pires, S. R. I. (2014). Making to availability: an application of the Theory of Constraints in make-to-stock environments. Project Management Journal, 21(1), 65-76. 
Souza, F. B., Rentes, A. F., \& Agostinho, L. O. (2002). The relationship between production planning and control systems and methods of capacity allocation. Project Management Journal, 9(2), 215-234.

It should read:

Pacheco, D. A. J., Lacerda, D. P., Corcini Neto, S. L. H., Jung, C. F., \& Antunes Júnior, J. A. V. (2014). Balanceamento de fluxo ou balanceamento de capacidade? análises e proposições sistêmicas. Gestão \& Produção, 21(2), 355-368. http://dx.doi.org/10.1590/S0104-530X2014005000006.

Souza, F. B., \& Baptista, H. R. (2010). Proposta de avanço para o método TamborPulmão-Corda Simplificado aplicado em ambientes de produção sob encomenda. Gestão \& Produção, 17(4), 735-746. http://dx.doi.org/10.1590/S0104530X2010000400008.

Souza, F. B., \& Pires, S. R. I. (1999). Análise e proposições sobre o balanceamento e uso de excesso de capacidade em recursos produtivos. Gestão \& Produção, 6(2), 111-126. http://dx.doi.org/10.1590/S0104-530X1999000200004.

Souza, F. B., \& Pires, S. R. I. (2014). Produzindo para disponibilidade: uma aplicação da Teoria das Restrições em ambientes de produção para estoque. Gestão \& Produção, 21(1), 65-76. http://dx.doi.org/10.1590/S0104-530X2013005000007.

Souza, F. B., Rentes, A. F., \& Agostinho, O. L. (2002). A interdependência entre sistemas de controle de produção e critérios de alocação de capacidades. Gestão \& Produção, 9(2), 215-234. http://dx.doi.org/10.1590/S0104-530X2002000200008.

The authors apologize for the errors. 